\title{
The 100th volume of "Archives" appeared 100 years ago
}

\author{
Klaus Diedrich · Hans Ludwig
}

Published online: 14 April 2013

(C) Springer-Verlag Berlin Heidelberg 2013

And the journal has survived since then. In 1913, "Archiv für Gynäkologie" celebrated the print of its 100th volume. At that time, the journal has been edited by Ernst Bumm, Berlin, and Ernst Wertheim, Vienna (Fig. 1). The leading article was contributed by the pathologist Robert Meyer under the title "About the relations of the ovarian cell and the impregnated ovarian cell to the follicular system as well as the corpus luteum to menstruation" [1]. The paper followed a lecture given by Meyer before the Berlin Society of Gynecology and Obstetrics on 28 February 1913. His concluding remarks were: "Anatomy can only hint on single causal connections, chemistry will have the last word". How prophetic at that time! There were nine beautiful drawings added, done by the author himself (Fig. 2). The 100th volume contains further articles about ovulation, radiation in genital cancers, chondrodystrophy, bacteraemia in the placenta, peritonitis in uterine rupture, endometrial cancer, endometritis or menstrual desquamation (by Hitschmann and Adler [2]), gonorrhoea, malignancy of the chorionic epithelium, disinfection in the puerperium, umbilical rupture and first investigations of the effects of placental extraction to the sexual organs of the female [3]. The leading researchers did not publish much, but when writing, they were scrupulous to put every detail into their paper. Articles spreading about more than 100 pages were not unusual. The entire spectre of the scientific approach at that time could be presented in that single volume. That tradition has been maintained up to the present and the translation of the journal into English in 1978 did not alter the concept.

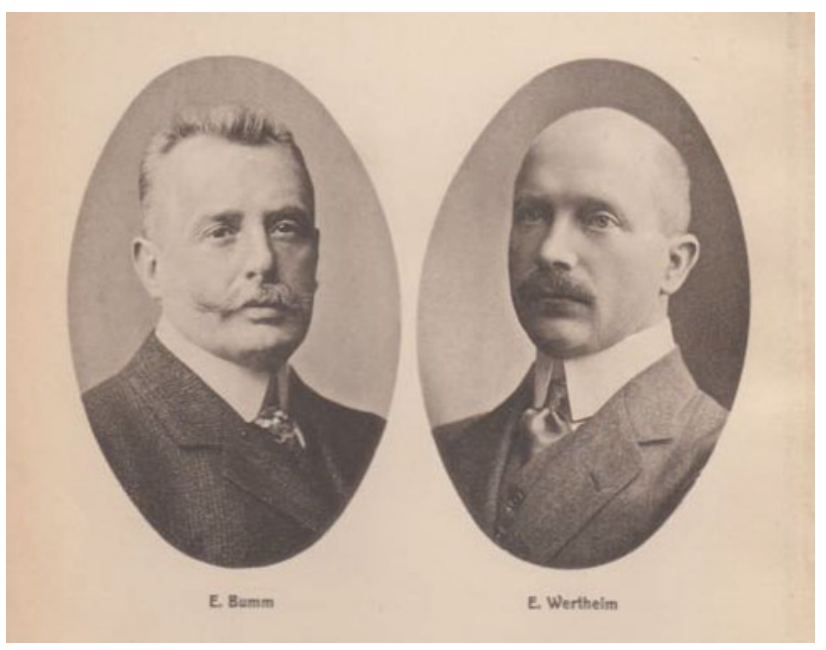

Fig. 1 Ernst Bumm, Berlin; Ernst Wertheim, Vienna: Editors, 1913 (from “Archiv für Gynäkologie”, volume 100, 1913)
K. Diedrich

Lübeck, Germany

H. Ludwig ( $\square$ )

Basel, Switzerland

e-mail: prof.ludwig@bluewin.ch 
Fig. 2 Robert Meyer: drawings of different sections of luteinized ovary, 1913 (from

"Archiv für Gynäkologie", volume 100, 1913)

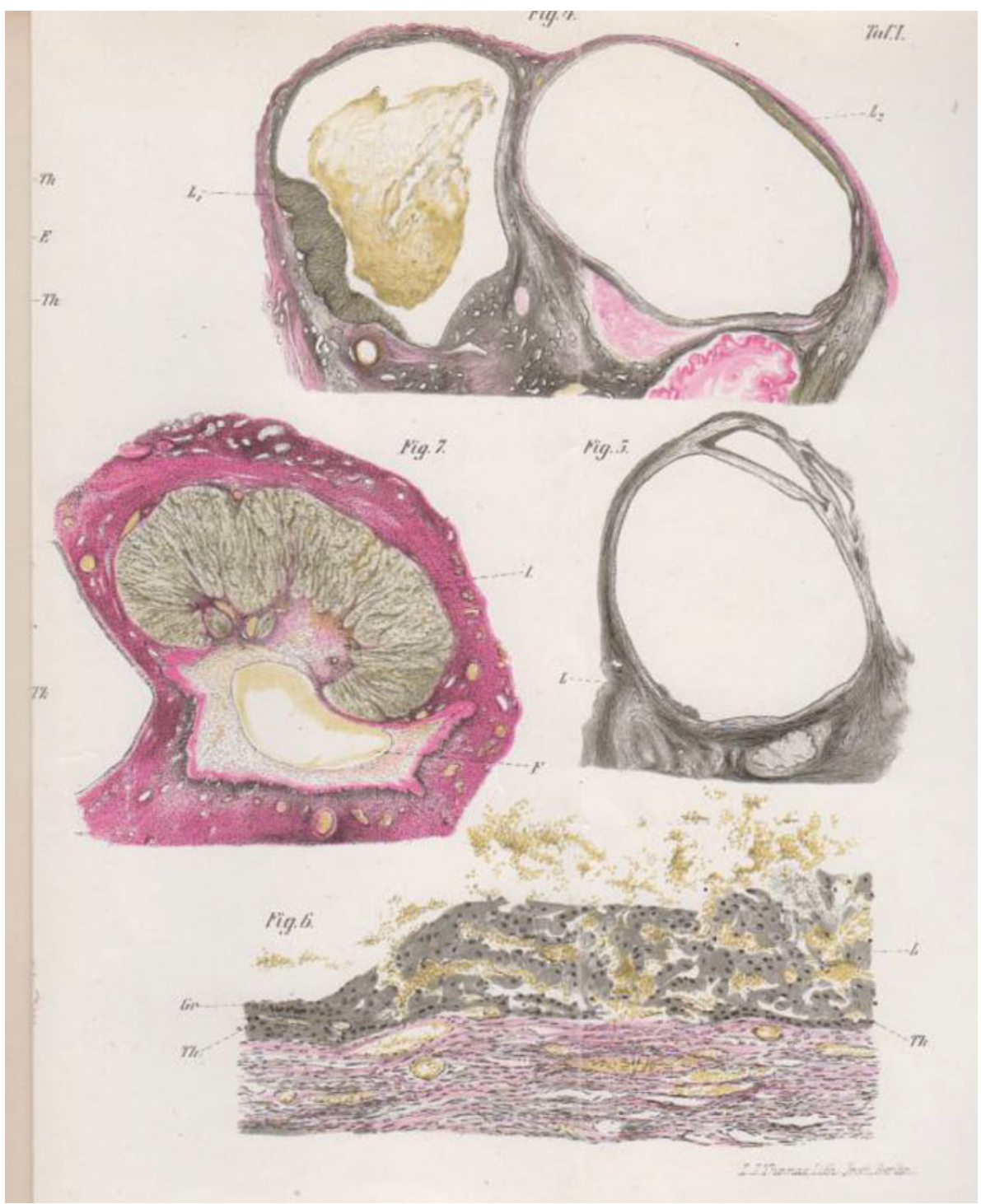

Conflict of interest None.

\section{References}

1. Meyer R (1913) Über die Beziehungen der Eizelle und des befruchteten Eies zum Follikelapparat, sowie das Corpus luteum zur Menstruation. Arch Gynäk 100:1-19
2. Hitschmann F, Adler L (1913) Ein weiterer Beitrag zur Kenntnis der normalen und entzündeten Uterusmukosa. Die Klinik der Endometritis unter besonderer Berücksichtigung der unregelmässigen Gebärmutterblutungen. Arch Gynäk 100:233-304

3. Fellner OO (1913) Experimentelle Untersuchungen über die Wirkung von Gewebeextrakten aus der Plazenta und den weiblichen Sexualorganen auf das Genitale. Arch Gynäk 100:641-719 